\title{
Aspek Hukum Penetapan Upah Minimum Kabupaten Batubara
}

\author{
${ }^{1}$ Suhairi ${ }^{2}$ Dr. Bahmid, S.H., M.Kn ${ }^{3}$ Dr. Mangaraja Manurung, S.H., M.H. \\ bahmid1979@gmail.com \\ mrajamanurung1970@gmail.com
}

Fakultas Hukum Universitas Asahan, Jl. Jend. Ahmad Yani Kisaran Sumatera Utara

\begin{abstract}
ABSTRAK
Penetapan suatu upah minimum kabupaten ditetapkan oleh peraturan gubernur yang menurut suatu kelayakan dan jumlah industry yang ada, setelah dilakukannya analisa mengenai suatu keadaan perekonomian didaerah maka akan ditetapkan mengenai kelayakan upah minimum tersebut. Maka dari itu suatu upah dapat dilaksanakan dan harus menyeluruh dan dijalankan kepada perusahaan yang mempunyai karyawan, maka dari itu keterbukaan mengenai suatu perusahaan harus dapat membantu pemerintah dalam menjalankan peraturan menganai upah tersebut.

Adapun rumusan masalah 1. Bagaimana arus Penetapan Upah Minimun di Kabupaten Batubara terhadap Undang-Undang Ketenagakerjaan. 2. Apa hambatan dalam penetapan Upah Minimun di Kabupaten Batubara.

Metode pendekatan yang digunakan metode penelitian yang bersifat empiris. Penelitian hukum empiris (yuridis empiris) adalah jenis penelitian hukum sosiologi dan dapat disebut pula dengan penelitian lapangan, yaitu mengkaji ketentuan hukum yang berlaku serta apa yang terjadi dalam kenyataannya di masyarakat.
\end{abstract}

\section{KataKunci:Upah, Minimum, Kabupaten, Batubara.}




\section{PENDAHULUAN}

Indonesia Negara dimana banyak perusahaan yang memiliki pegawai yang harus digaji karena itu pekerja/buruh dapat meminta hak sesuai dengan apa yang telah dihasilkan mengenai produksi barang dan jasanya, barang dan jasa tersebut kemudian merupakan suatu prestasi yang telah diciptakan oleh pegawai atau pegawai-pegawai yang bekerja disuatu perusahaan yang dipekerjakan tersebut oleh karena itu adanya suatu kelayakan mengenai upah yang

diterima pegawai berdasarkan peraturan undang-undang yang ditetapkan oleh pemerintah maupun ditetapkan oleh pemerintah daerah mengenai banyaknya industri ataupun perusahaan yang ada di daerahnya masing-masing, karena pekerja dan buruh merupakan suatu yang penting yang harus dimilik dalam menghasilkan barang dan jasa sesuai dengan aturan yang dtelah ditetapkan dalam undang-undang no 13 tahun 2003 tetang ketenagakerjaan, hak dan tanggung jawab telah ditaru dalam undang-undang tersebut dan persyaratan yang harus dijalankan oleh pekerja apabila ia telah bekerja dengan suatu perusahaan tersebut. ${ }^{1}$

Pekerja yang telah memenuhi syarat dan telah bekerja yang secara jasmani dan rohani dapat mengerjakan apa yang sesuai dengan produksi barang dan jasa suatu perusahaan dapat memenuhi apa yang menjadi kewajibannya dalam sautu perusahaan maka ia harus dapat memenuhi apa yang menjadi pekerjaanya itu, dari sana kita dapat

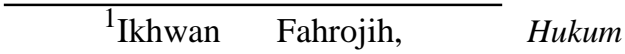
Perburuhan Konsepsi, Sejarah, dan Jaminan Konstitusional, Malang:Setara Press, 2016, hal. 29 ketahui bahwa tugas dari seorang pegawai selain menjalankan apa yang telah ditetapkan perusahaan ia pun harus mendapatkan upah setelah ia bekerja, maka dengan itu upah yang didapat harus sesuai dengan apa yang ia hasilakan dan ia kerjakan sudah barang tentu mengenai hak-hak dan jaminan itu harus ia dapat apabila pada saat perjanjian kerja ia dan pihak penerima telah memperjanjian tentang kesejahteraanya ketika ia bekerja dan ia juga dapat mendapatkan hak-hak pekerjaanya ketika ia bekerja dan ada hal-hal yang dapat membahayakanya ketika ia bekerja sepereti contoh bentuk- bentuk hak yang didapat dan merupakan kewajiban perusahaan dalam mempekerjakan pegwai atau pekerja/buruh yang ia jadikan sebagai pekerja.

Bentuk-bentuk kesejahteraan yang diberkan seperti gaji pokok yang diteriamnya pada akhir bulan atau yang telah ditetapakan dalam perjanjian pada saat kerja, maka dari itu kesejahteraan mengenai kesehatan melalui BPJS atau jamsostek jaminan gaji pension apabila ia telah ditetapkan menjadi pegawai tetap dan pegawai yang telah mencukupi usia yang ditetapkan undang-undang nomor 13 tahun 2003 tentang pekerja , mengenai pesangon, beras catu tempat tinggal, tunjangan hari raya dan sebagainya merupakan kewajiban perusahaan dalam memberikannya karena telah diatur dalam undangundang.$^{2}$ dalam hal pekerja tersebut menetap di suatu perusahaan yang, maka telah disediakan tempat tinggal bagi pekerja/buruh tersebut.

\footnotetext{
${ }^{2}$ Aloysius Uwiyono, Asas-Asas Hukum Perburuhan, Jakarta: Raja Grafindo Persada, 2014, hal. 97.
} 
Untuk melakukan penetapan bagi pekerja atau buruh harus sesuai dengan umk (upah minimum kabupaten yang telah digagas oleh pemerintah melalui penetapan peraturan gubernur ataupun undangundang-undang maka dari itu suatu pelaksanaan dapat dijalankan mengingat dinas ketenagakerjaan harus pro aktif dalam memenuhi apa yang menjadi hak para pekerja untuk mendapatkan keadilan tanpa adanya diskriminasi dan tidak dijalankan ${ }^{3}$

Kabupaten

Batubara merupakan salah satu kabupaten yang masih muda, setelah dimekarkan dari

Kabupaten Asahan banyak mengalami perubahan dalam bidang pembangunan dan aspek kehidupan lainnya. Perubahan ini tentunya menjadi hal yang baik untuk kesejahteraan masyarakat Kabupaten Batubara. Di Kabupaten Batubara banyak perusahaan yang beroperasi, mulai dari sektor perkebunan kelapa sawit, perkebunan karet, industri pengelohan kepala sawit, industri pengeolahan aluminium, perusahaan eksport import di Pelabuhan Kuala Tanjung, industri pengelohaan ikan, industri rumah tangga dan lain sebagainya.

Tentunya dalam hal ini Pemerintah Kabupaten Batubara bertanggungjawab atas kesejahteraan tenaga kerja yang ada di Kabupaten Batubara dengan menetapkan Upah Minimum sesuai dengan kebutuhan masyarakat dan kemampuan perusahaan tersebut. Penetapan upah minimun kabupaten ini tentunya harus berpedoman pada UndangUndang Ketenagakerjaan. Pekerja yang telah memenuhi syarat dan telah bekerja yang secara jasmani dan rohani dapat mengerjakan apa yang sesuai dengan produksi barang dan jasa suatu perusahaan dapat memenuhi apa yang menjadi kewajibannya dalam sautu perusahaan maka ia harus dapat memenuhi apa yang menjadi pekerjaanya itu, dari sana kita dapat ketahui bahwa tugas

dari seorang pegawai selain menjalankan apa yang telah ditetapkan perusahaan ia pun harus mendapatkan upah setelah ia bekerja, maka dengan itu upah yang didapat harus sesuai dengan apa yang ia hasilakan dan ia kerjakan sudah barang tentu mengenai hak-hak dan jaminan itu harus ia dapat apabila pada saat perjanjian kerja ia dan pihak penerima telah memperjanjian tentang kesejahteraanya ketika ia bekerja dan ia juga dapat mendapatkan hak-hak pekerjaanya ketika ia bekerja dan ada hal-hal yang dapat membahayakanya ketika ia bekerja sepereti contoh bentuk- bentuk hak yang didapat dan merupakan kewajiban perusahaan dalam mempekerjakan pegwai atau pekerja/buruh yang ia jadikan sebagai pekerja.

Dari uraian permasalahaan di atas, penulis sangat tertarik untuk melakukan penelitian sebagai salah satu syarat meraih gelar sarjana hukum di Universitas Asahan yaitu tentang Upah Minimun Kabupaten, sebagai wujud dari kesejahteraan pekerja yang dijanjikan oleh pemerintah. Judul penelitian ini yaitu Aspek Hukum Penetapan Upah Minimum Kabupaten Batubara.

\section{PERUMUSAN MASALAH}

\footnotetext{
${ }^{3}$ Adrian Sutedi, Hukum Perburuhan, Jakarta:Sinar Grafika, 2009, hal. 16
} 
Adapunrumusanmasalah yang diangkatdalamtulisaniniadalahsebaga iberikut:

1. Bagaimana arus Penetapan Upah Minimun di Kabupaten Batubara terhadap UndangUndang Ketenagakerjaan.

2. Apa hambatan dalam penetapan Upah Minimun di Kabupaten Batubara.

\section{METODE PENELITIAN}

Metode pendekatan yang digunakan metode penelitian yang bersifat empiris. Penelitian hukum empiris (yuridis empiris) adalah jenis penelitian hukum sosiologi dan dapat disebut pula dengan penelitian lapangan, yaitu mengkaji ketentuan hukum yang berlaku serta apa yang terjadi dalam kenyataannya di masyarakat.

\section{PEMBAHASAN}

Penetapan Upah Minimun Di Kabupaten Batubara Terhadap Undang-Undang Ketenagakerjaan.

1. Kondisi Geografis dan Penduduk Kabupaten Batubara

Kabupaten Batubara

merupakan kabupaten hasil pemekaran dari Kabupaten Asahan mempunyai wilayah luas $904,96 \mathrm{~km}^{2}$ terdiri dari 7 (tujuh) kecamatan dan 10 kelurahan serta 141 desa. Kabupaten Batubara terletak antara $2^{0} 0300 "-3^{0} 26^{\prime} 00$ " lintang utara dan $99^{0} 01^{\prime}-100^{0} 00$ ' bujur timur. Hampir semua wilayah daratan Kabupaten

pekerja/buruh dapat meminta hak sesuai dengan apa yang telah

dihasilkan mengenai produksi barang dan jasanya, barang dan jasa tersebut kemudian merupakan suatu prestasi yang telah diciptakan oleh pegawai atau pegawai-pegawai yang bekerja disuatu perusahaan yang dipekerjakan tersebut oleh karena itu adanya suatu kelayakan mengenai upah yang

diterima pegawai berdasarkan peraturan undang-undang yang ditetapkan oleh pemerintah maupun ditetapkan oleh pemerintah daerah mengenai banyaknya industri ataupun perusahaan yang ada di daerahnya masing-masing, karena pekerja dan buruh merupakan suatu yang penting yang harus dimilik dalam menghasilkan barang dan jasa sesuai dengan aturan yang dtelah ditetapkan dalam undang-undang no 13 tahun 2003 tetang ketenagakerjaan, hak dan tanggung jawab telah ditaru dalam

undang-undang tersebut dan persyaratan yang harus dijalankan oleh pekerja apabila ia telah bekerja dengan suatu perusahaan tersebut. ${ }^{4}$

\section{Penetapan Upah Kabuapten Batubara \\ Penetapan suatu upah minimum} kabupaten ditetapkan oleh peraturan gubernur yang menurut suatu kelayakan dan jumlah industry yang ada, setelah dilakukannya analisa

mengenai suatu keadaan perekonomian didaerah maka akan ditetapkan mengenai kelayakan upah minimum tersebut. Maka dari itu suatu upah dapat dilaksanakan dan harus menyeluruh dan dijalankan kepada perusahaan yang mempunyai karyawan, maka dari itu keterbukaan mengenai suatu perusahaan harus dapat membantu pemerintah dalam 
menjalankan ${ }_{\text {upah tersebut. }}$ peraturan menganai
and pekerja/buruh dapat meminta hak sesuai dengan apa yang telah dihasilkan mengenai produksi barang dan jasanya, barang dan jasa tersebut kemudian merupakan suatu prestasi yang telah diciptakan oleh pegawai atau pegawai-pegawai yang bekerja disuatu perusahaan yang dipekerjakan tersebut oleh karena itu adanya suatu kelayakan mengenai upah yang diterima pegawai berdasarkan peraturan undang-undang yang ditetapkan oleh pemerintah maupun ditetapkan oleh pemerintah daerah mengenai banyaknya industri ataupun perusahaan yang ada di daerahnya masing-masing, karena pekerja dan buruh merupakan suatu yang penting

yang harus dimilik dalam menghasilkan barang dan jasa sesuai dengan aturan yang dtelah ditetapkan dalam undang-undang no 13 tahun 2003 tetang ketenagakerjaan, hak dan tanggung jawab telah ditaru dalam undang-undang tersebut dan persyaratan yang harus dijalankan oleh pekerja apabila ia telah bekerja dengan suatu perusahaan tersebut

Peranan pemerintah dalam mengawasi pelaksanaan Peraturan MenteriTenaga Kerja dan Transmigrasi Nomor 7 Tahun 2013 tentang UpahMinimum untuk Penetapan Upah Minimum

Kabupaten/Kota, dikaitkandengan contoh hasil penelitian yang ditemukan di lapanganmemperlihatkan bahwa fungsi yang dilakukan oleh Pegawai PengawasKetenagakerjaan belum optimal.

\footnotetext{
${ }^{5}$ Ibid, hal. 11
}

Penetapan Upah Minimum yang dipergunakan di Kabupaten batubara adalah UpahMinimum Kabupaten/Kota (UMK).Penetapan Upah Minimum Kabupaten Batubara berdasarkan Undang-Undang Nomor 13 Tahun 2003 tentang Ketenagakerjaan, kemudian Peraturan Menteri Tenaga Kerja dan Trasmigrasi Republik Indonesia Nomor 7 Tahun 2013 tentang Upah Minimum serta Peraturan Pemerintah Republik Indonesia Nomor 78 Tahun 2015 tentang Pengupahan. ${ }^{6}$

Selain itu dasar hukum tentang penentuan upah minimum di Kabupaten Batubara dilakukan menggunakan mekanisme yangberlaku yaitu sesuai dengan

Peraturan Menteri Tenagakerja danTransmigrasi tentang Komponen dan Pelaksanaan Tahapan Pencapaian Kebutuhan Hidup Layak (KHL) sesuai dengan Peraturan Menteri

Tenaga Kerjadan Transmigrasi Nomor21 Tahun 2016 tentang Kebutuhan Hidup Layak (KHL) ${ }^{7}$

Penetapan upah minimum yang dilakukan pemerintah Kabupaten Batubara dilakukan dengan mempertimbangkan: ${ }^{8}$

a. Dewan Pengupah Daerah Kabupaten Batubara

b. Laju Pertumbuhan di Kabuapetan Batubara 
c. Tingkat Inflasi Kabuapten Batubara

d. Nilai Upah Minimum Kabupaten Batubara sebelumnya.

\section{Peranan Dewan Pengupah}

DewanPengupahan

Kabupaten Batubara dalam melakukan penetapan upah minimum melakukan proses penetapan upah minimum kabupaten didahului dengan pembahasan pada Dewan

Pengupahan Daerah. Setelah berlakunya Peraturan Pemerintah Nomor 78 Tahun 2015 tentang Pengupahan, kenaikan upah minimu kabupaten ditentukan melalui formula yang didasarkan pada persentase pertumbuhan ekonomi dan laju inflasi kemudian dikalikan dengan upah minimum kabupaten tahun berjalan. ${ }^{9}$ pekerja/buruh dapat meminta hak sesuai dengan apa yang telah dihasilkan mengenai produksi barang dan jasanya, barang dan jasa tersebut kemudian merupakan suatu prestasi yang telah diciptakan oleh pegawai atau pegawai-pegawai yang bekerja disuatu perusahaan yang dipekerjakan tersebut oleh karena itu adanya suatu kelayakan mengenai upah yang diterima pegawai berdasarkan peraturan undang-undang yang ditetapkan oleh pemerintah maupun ditetapkan oleh pemerintah daerah mengenai banyaknya industri ataupun perusahaan yang ada di daerahnya masing-masing, karena pekerja dan buruh merupakan suatu yang penting yang harus dimilik dalam menghasilkan barang dan jasa sesuai dengan aturan yang dtelah ditetapkan dalam undang-undang no 13 tahun

\footnotetext{
${ }^{9}$ Wawancara dengan Bapak Abdul Aziz sebagai Ketua Apindo Kabupaten Batubara, pada tanggal 16 September 2019
}

2003 tetang ketenagakerjaan, hak dan tanggung jawab telah ditaru dalam

undang-undang tersebut dan persyaratan yang harus dijalankan oleh pekerja apabila ia telah bekerja dengan suatu perusahaan tersebut

\section{KESIMPULAN DAN \\ SARAN Kesimpulan}

Sesuai dengan suatu kelayakan hidup yang ada pada daerah batubara maka kebutuhan hidup layak yang ada dikabupaten batu bara harus dipenuhi oleh perusahaan dan sesuai dengan peraturan undang-undang yang berlaku serta peraturan-peraturan lain yang menyatakan penetapan pekerja/buruh dapat meminta hak sesuai dengan apa yang telah dihasilkan mengenai produksi barang dan jasanya, barang dan jasa tersebut kemudian merupakan suatu prestasi yang telah diciptakan oleh pegawai atau pegawai-pegawai yang bekerja disuatu perusahaan yang dipekerjakan tersebut oleh karena itu adanya suatu kelayakan mengenai upah yang

diterima pegawai berdasarkan peraturan undang-undang yang ditetapkan oleh pemerintah maupun ditetapkan oleh pemerintah daerah mengenai banyaknya industri ataupun perusahaan yang ada di daerahnya masing-masing, karena pekerja dan buruh merupakan suatu yang penting yang harus dimilik dalam menghasilkan barang dan jasa sesuai dengan aturan yang dtelah ditetapkan dalam undang-undang no 13 tahun 2003 tetang ketenagakerjaan, hak dan tanggung jawab telah ditaru dalam undang-undang tersebut dan persyaratan yang harus dijalankan oleh pekerja apabila ia telah bekerja dengan suatu perusahaan tersebut 
Hambatan yang dihadapai dalam penetapan upah minimu di Kabupaten Batubara yaitu kurang optimalnya fungsi dari Pengawasanketenagakerjaan, dimana Pegawai PengawasKetenagakerjaan tidak memiliki kewenangan untuk menindak apabiladitemukan terjadinya pelanggaran terhadap peraturan perundangan terkaitbaik bidang Ketenagakerjaan maupun bidang pengupahan. Sehingga halini menyebabkan masih bisa ditemukannya pelanggaranpelanggaran yangdilakukan oleh pihak pengusaha. Hambatan lainnya adanya faktor internal dan faktor eksternal dari Dewan Pengupahan Kabupaten Batubara.

\section{Saran}

Bahwa belum menyeluruhnya suatu keterbukaan mengenai pengupahan yang dijalankan suatu perusahaan dan badan hukum yang memiliki pekerja yang harus sesuai dengan upah minimum kabupaten, karna pada hakikatnya harus adanya kesusuian mengenai apa yang dinamakan suatu pegawai maka pegawai wajib mendapatkan hak sesuai pengaturan mengenai upah minimum kabupaten yang telah dikeluarkan berdasarkan peraturan undang-undang maupun peraturan gubernur beserta peraturan daerah yang menetapkan pengupahan. Maka dalam ha itu seluruh perusahaan yang ada di kabupaten batubara harus

menetapkan upah minimum kabupaten yang sesuai dengan kebutuhan hidup layak dikabupeten batubara.

\section{DAFTAR PUSTAKA}

\section{A. Buku}

Adrian Sutedi, Hukum

Perburuhan, Jakarta:Sinar Grafika, 2009.

Aloysius Uwiyono, Asas-Asas Hukum Perburuhan, Jakarta: Raja Grafindo Persada, 2014.

Dinas Kependudukan dan Pencatatan Sipil

Kabupaten Batubara, Profil Perkembangan Kependudukan Kabupaten Batubara2018, Limapuluh, 2019.

Ikhwan Fahrojih, Hukum Perburuhan Konsepsi, Sejarah, dan Jaminan

Konstitusional,

Malang:Setara Press, 2016.

Saifuddin Bachrun, Menyusun Struktur dan Skala Gaji dalam praktik, PPM Manajemen, Jakarta, 2011.

\section{B. Peraturan Perundang- undangan}

Undang - undang Dasar Negara Republik Indonesia 1945.

\section{Wawancara}

Wawancara dengan Bapak Abdul

Aziz sebagai Ketua

Apindo Kabubaten

Batubara, pada tanggal 16

September 2019.

Wawancaradengan Bapak Akhyarruddin Matondang, Aparatur Sipil Negara pada Dinas Tenaga Kerja Kabupaten Batubara, pada tanggal 16 September 2019 Wawancaradengan Bapak Syahrizal Aparatur Sipil Negara pada Dinas Tenaga Kerja Kabupaten Batubara, 
pada tanggal 16 September

2019

Wawancara dengan Bapak Abdul

Aziz sebagai Ketua Apindo

Kabupaten Batubara, pada

tanggal 16 September 2019 